KHAZANAH MULTIDISIPLIN

VOL 1 NO 22020

https://journal.uinsgd.ac.id/index.php/kl

\title{
OPPORTUNITIES BAITUL MAAL WAT TAMWIL (BMT) IN INCREASING SMALL BUSINESS ACTIVITIES IN THE COMMUNITY
}

\author{
Iis Suhaeni \\ Department of Syariah Economic, UIN Sunan Gunung Djati Bandung, Indonesia \\ E-mail: iissuhaeni2@gmail.com
}

Diterima : 1 September 2020, Revisi : 5 November 2020 Disetujui : 6 November 2020

\begin{abstract}
The writing of this article aims to find out how the Baitul Maal wat Tamwil (BMT) opportunity to participate in improving the welfare of the middle class by contributing for supporting community small business activities by providing financial products that can be accepted and utilized by the community. Baitul Maal wat Tamwil (BMT) in addition to having social functions such as collecting, managing and distributing zakah, infaq and alms funds, Baitul Maal wat Tamwil (BMT) also functions as a profit-oriented business entity by collecting savings and providing financing for small business actors Besides that, Baitul Maal wat Tamwil (BMT) is expected to be able to help the community so that they can completely avoid interest-based loans to build their businesses, especially from moneylenders.
\end{abstract}

Keywords: Baitul Maal wat Tamwil (BMT)

\begin{abstract}
ABSTRAK
Penulisan artikel ini bertujuan untuk mengetahui bagaimana peluang Baitul Maal wat Tamwil (BMT) untuk ikut serta dalam meningkatkan kesejahteraan masyarakat menengah dengan cara memberikan kontribusi dalam mendukung kegiatan usaha kecil masyarakat dengan cara menyediakan produk keuangan yang dapat diterima dan dimanfaatkan oleh masyarakat. Baitul Maal wat Tamwil (BMT) selain memiliki fungsi sosial seperti menghimpun, mengelola dan menyalurkan dana zakat, infaq dan sedekah, Baitul Maal wat Tamwil (BMT) juga berfungsi sebagai badan usaha profit oriented dengan cara menghimpun tabungan dan memberikan pembiayaan bagi pelaku kegiatan usaha kecil, selain itu Baitul Maal wat Tamwil (BMT) diharapkan akan dapat membantu masyarakat agar sepenuhnya bisa menjauhi pinjaman yang berbasis bunga untuk membangun usahanya terutama dari rentenir.
\end{abstract}

Kata kunci: Baitul Maal wat Tamwil (BMT)

\section{INTRODUCTION}

Baitul Maal wat Tamwil (BMT) is a business entity with two orientations, first as baitul mall, which means that property houses have non-profit oriented social activities including collecting zakat, infaq, alms and grant funds and distributing them proportionally. Secondly as baitut tamwil which means business houses have profit-oriented activities including activities such as those carried out by cooperatives, nam ely raising 
KHAZANAH MULTIDISIPLIN

VOL 1 NO 22020

https://journal.uinsgd.ac.id/index.php/kl

funds such as fees and savings then disbursed to economic actors to advance productive business units so as to help the quality of life of small and medium-sized entrepreneurs in its economic field.

Baitul Maal wat Tamwil (BMT) was established with the aim of improving and improving the economic quality of the community in general, and in particular to improve the welfare of members of the Baitul Maal wat Tamwil (BMT) concerned. Baitul Maal wat Tamwil (BMT) has a great opportunity to play a role in the progress of the country's economy, by developing micro, small and medium enterprises in the community financed by Baitul Maal wat Tamwil (BMT) can gradually reduce poverty and unemployment so as to increase per capita income Public. Baitul Maal wat Tamwil (BMT) is a business that is independent and is grown independently by the community around Baitul Maal wat Tamwil (BMT) Baitul Maal wat Tamwil (BMT) and is managed professionally.

Baitul Maal wat Tamwil (BMT) as an institution engaged in providing financial services to the lower middle class or unbankable (not affordable by banking services) because it does not have high value goods to be used as collateral when applying for financing to Islamic banks. The system of Baitul Maal wat Tamwil (BMT) is almost the same as a cooperative. Therefore, Baitul Maal wat Tamwil (BMT) is also commonly referred to as a sharia cooperative because Baitul Maal wat Tamwil (BMT) observes and applies sharia principles in all its operational activities.

The writing of this article aims to find out how the Baitul Maal wat Tamwil (BMT) opportunity to participate in improving the welfare of the middle community by contributing in supporting community small business activities by providing financial products that can be accepted and utilized by the community, especially the middle to under.

Baitul Maal wat Tamwil (BMT) is a microfinance institution that supports the economic activities of small and medium-sized communities based on sharia (Sholahuddin, 2011). Financial institutions that operate using profit sharing principles such as mudharabah and musharaka, to 
develop micro, small and medium-sized business enterprises in order to be able to raise degrees and improve the welfare of the poor or middle-poor. Founded on the initiative and efforts and initial capital of several local communities and using the salaam economic system as its foundation, the salaam economic system is safety or core with justice, peace and prosperity. (Arif, 2012).

Baitul Maal wat Tamwil (BMT) is a micro-Islamic financial institution. As a financial institution, BMT carries out thefunction of raising funds and channeling them. As the name implies, there are two main functions of Baitul Maal wat Tamwil (BMT), which are:

First, Baitul Tamwil (house of wealth development), functions to develop productive businesses and investments in order to improve the economic quality of micro entrepreneurs, including by encouraging saving activities and supporting the financing of economic activities of micro, small and medium-sized businesses that experience difficulties in their business because lack of funds.

Second, Baitul mall (house of treasures), its function is to receive deposits of alms, infaq and alms, also optimize the distribution of these deposits in accordance with the regulations or mandate specified (Arif, 2012). Indonesia, which is predominantly Muslim, has great zakat potential, if all can be collected and optimally managed by financial institutions such as BMT, it will encourage the progress of the Indonesian economy.

The legal basis for BMT's activities is contained in several letters in the Holy Qur'an (Dewi, 2017), including:

Al-Quran Surah At-Taubah verse 103

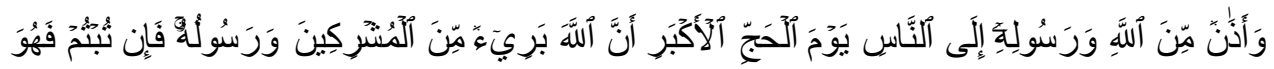

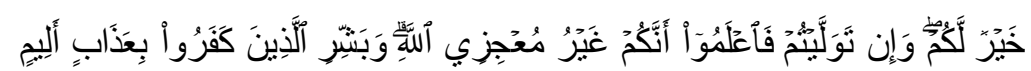

of their goods, take alms, that so Thou mightest purify and sanctify them; and pray on their behalf. Verily Thy prayers are a source of secu rity for them: and Allah is one who heareth and knoweth. 
KHAZANAH MULTIDISIPLIN

VOL 1 NO 22020

https://journal.uinsgd.ac.id/index.php/kl

Al-Qur'an Surat Al-Baqarah ayat 279

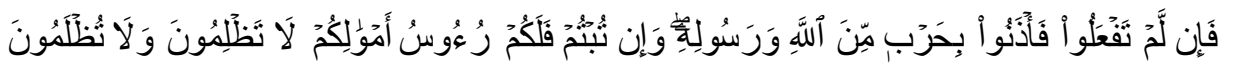

and if You do not do it, Then take a notice of war from Allâh and his Messenger but if You repent, You shall have Your capital sums. deal not unjustly (by asking more than Your capital sums), and You shall not be dealt with unjustly (by receiving less than Your capital sums).

Hadiht history Sunan Nasa'I Number 4483

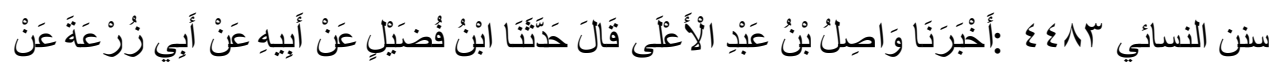
أبِي هُرَيْرَةَفَالَ

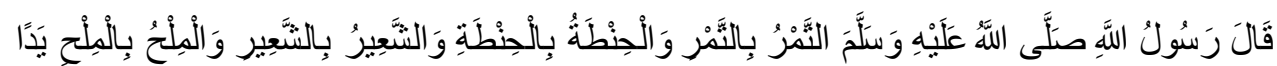

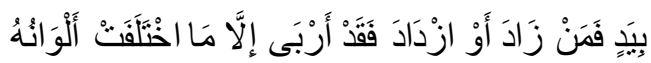

Sunan Nasa'i : Having told us Washil bin Abdul A'la, he said: told us Ibn Fudhail from his father from Abu Zur'ah from Abu Hurairah, he said: The Messenger of Allah sallallaahu 'alaihi wa sallam said: "Dates with dates, wheat with wheat, barley with barley, salt with salt with handover directly, anyone who adds or asks for additional then reallyhe has made usury except for a different color."

In addition to the legal basis contained in the Qur'an and the Hadith. Baitul Maal wat Tamwil (BMT) has another positive legal basis (Imaniyati, 2010), including:

1. Law No. 23 of 2011 concerning Management of Zakat

2. Law No. 25 of 1992 concerning Cooperatives

3. UU no. 25 of 1992 concerning cooperatives was changed to Law No. 17 of 2012 concerning cooperatives. However, in 2014 Law No. 17 of 2012 was canceled by the Court, then the Act does not have binding legal force.

4. Law No. 1 of 2013 concerning Microfinance Institutions.

5. Law No. 21 of 2011 concerning the Financial Services Authority.

6. Regulation of the Minister of Cooperatives Number 11 of 2017 concerning Savings and Loan Business Activities and Sharia Financing by the Cooperative (Mursid, 2018). 
KHAZANAH MULTIDISIPLIN

VOL 1 NO 22020

https://journal.uinsgd.ac.id/index.php/kl

Baitul Maal wat Tamwil (BMT) has the characteristics of an independent, not closed, not a follower of a particular party or group, oriented to increasing the productivity of savings and or financing to develop productive economic activities for the surrounding com munity and members as well as social welfare, especially micro, medium and The poor (Prastiawati \& Darma, 2016).

Baitul Maal wat Tamwil (BMT) has the main characteristics as follows: (1) business oriented, (2) not a social institution even though it is used for activities for the welfare of many people such as zakat, infaq, and almsgiving (3) established from below on the role and participation of the community, (4) does not belong to individuals, but belongs to the small and lower communities around the neighborhood (Ridwan, 2004).

Based on the explanation that has been described, it can be seen that Baitul Maal wat Tamwil (BMT) must formulate procedures or operational standard procedures that are simple, easily established and easily handled by the community, especially by middle-to-lower-level customers whose majority of education is low. The mechanism and working rules of Baitul Maal wat Tamwil (BMT) can be made effectively, efficiently and flexibly so as not to complicate customers in the opportunity to use their facilities.

As for the main Baitul Maal wat Tamwil (BMT) principles including devotion and faith in Allah swt; cohesiveness (kaffah); kinship; togetherness; independence; professionalism; and istiqomah; after reaching or through one stage, continue to advance to the next stage, hoping only to Allah SWT(Aziz, 2005).

Baitul Maal wat Tamwil (BMT) was founded on the basis of a greeting community, which is full of safety, peace and prosperity. The basic principles established by Baitul Maal wat Tamwil (BMT) are as follows: (1) the quality of the best work, satisfying all parties and in accordance with the values of greetings; (2) Barakah or empowered and effective; (3) Spiritual communication or strengthening the values of Ruhiyah; (4) Democratic, participatory and inclusive; (5) Social justice and non-discrimination; (6) 
KHAZANAH MULTIDISIPLIN

VOL 1 NO 22020

https://journal.uinsgd.ac.id/index.php/kl

Friendly to the environment; (7) Wise local culture and knowledge; (8) Continuity (Arif, 2012).

\section{RESEARCH METHOD}

The method used in this research is the study of literature which is a research method by collecting written data, reading and recording library research, and then processed to build a framework that has a unified whole (Zed, 2008). This type of research through literature is commonly referred to as library research (Arikunto, 2008). Written data previously mentioned can be in the form of books, newspapers, journals, magazines, other reference books related to Baitul Maal wat Tamwil (BMT).

\section{RESULT AND DISCUSSION}

The level of health of the Baitul Maal wat Tamwil (BMT) is one measure of the quality and performance of the Baitul Maal wat Tamwil (BMT), it is considered from the things or factors that influence the business continuity, success and smoothness of the business in the Baitul Maal wat Tamwil (BMT), both for the short term or long term. Baitul Maal wat Tamwil (BMT) is one of the financial institutions that supports the economic efforts of the people, especially small and medium sized people so it is important to know the level of health of Baitul Maal wat Tamwil (BMT). Safe, trusted and useful are the three conditions that reflect the healthy Baitul Maal wat Tamwil (BMT) (Aziz, 2005).

The Baitul Maal wat Tamwil health can be seen from the aspects of the Ahmadiyya and Ruhiyah aspects (Aziz, 2005). The aspects of the service include financial perform ance as well as institutional and management. The aspects of Ruhiyah include the vision and mission of Baitul Maal wat Tamwil, social sensitivity, a strong sense of belonging and the implementation of sharia principles.

The development of Baitul Maal wat Tamwil (BMT) is the same as a variety of other business entities, there are several things that become obstacles in their business activities, these constraints can come from internal Baitul Maal wat Tamwil (BMT) itself or from external Baitul Maal 
KHAZANAH MULTIDISIPLIN

VOL 1 NO 22020

https://journal.uinsgd.ac.id/index.php/kl

wat Tamwil (BMT)).

Internal constraints faced by Baitul Maal wat Tamwil (BMT) is that capital is still small while the needs of community funds are large enough so that Baitul Maal wat Tamwil (BMT) has not been able to fully meet the community funding needs, both in the amount provided and in determining the payment period. relatively brief financing.

In addition, the internal obstacles in the Baitul Maal wat Tamwil (BMT) business activities are human resources or employees who do not have enough knowledge, both regarding the management of Baitul Maal wat Tamwil (BMT) or in dealing with new problems that may occur in community environment so that there are no innovations in products and services in Baitul Maal wat Tamwil (BMT).

While external constraints faced by Baitul Maal wat Tamwil (BMT) in their business activities are competition and marketing, in the competition Baitul Maal wat Tamwil (BMT) can be outdone by other financial institutions, both conventional banks or even moneylenders who offer large funds with additional or interest small and fast service and disbursement process. As for the marketing of Baitul Maal wat Tamwil (BMT), it is already widely known by the public, there are still many people who prefer to submit capital to loan sharks. (Arif, 2012), this shows that Baitul Maal wat Tamwil (BMT) still has to work hard in gaining public trust.

Previously it has been explained that the purpose of establishing Baitul Maal wat Tamwil (BMT) is to improve the economic quality and welfare of small and medium-sized communities so that it is expected to reduce poverty and develop the country's economy in general by continuing to encourage micro, small and medium businesses. The following is a picture showing the demographics of the poor until March 2019 obtained from the official BPS website (Badan Pusat Statistik, 2019). 
KHAZANAH MULTIDISIPLIN

VOL 1 NO 22020

https://journal.uinsgd.ac.id/index.php/kl

Picture. 1 Amount and Percentage of Poor Population 2005- March 2019

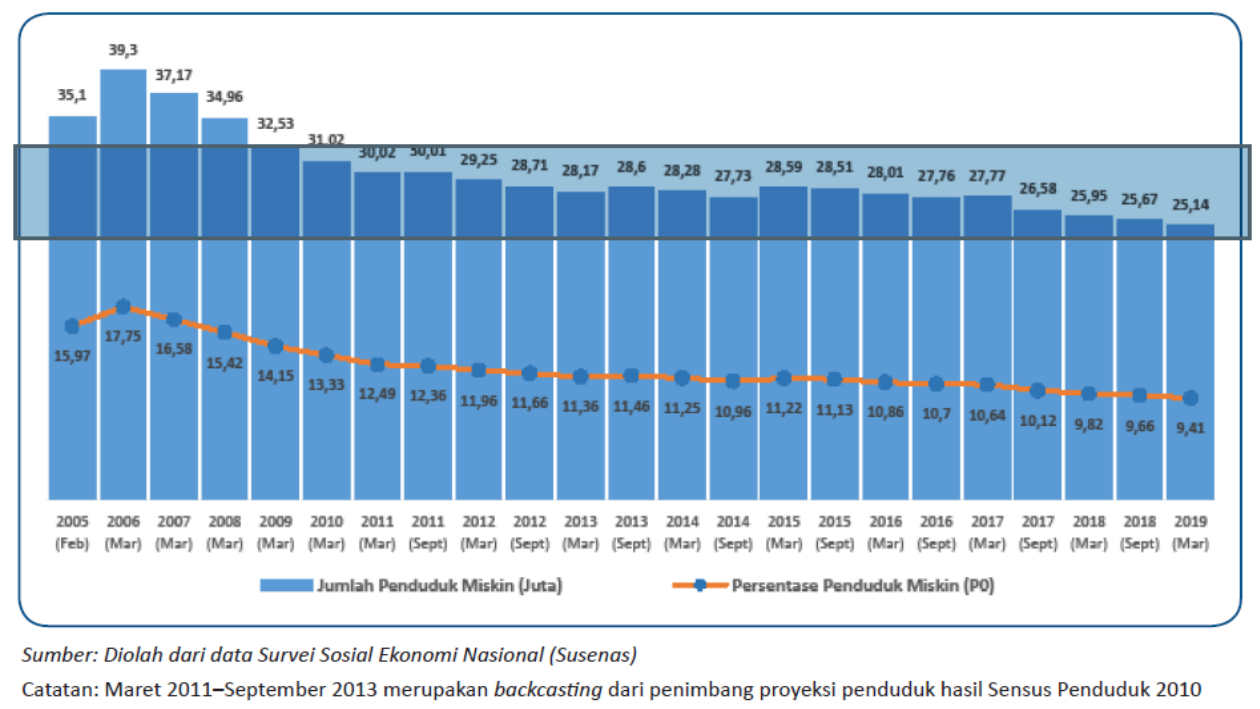

Judging from this figure, it can be seen that the number of poor people has increased and decreased fluctuatively from 2005 to 2017, then after 2017 the number of poor people has decreased every year until March 2019. This is a picture that shows the conditions that good because the last four years the number of poor people in Indonesia continues to experience decline.

If related to the role of Baitul Maal wat Tamwil (BMT), the progressive development of Baitul Maal wat Tamwil (BMT) in Indonesia is inseparable from the large portion of the middle andlower classes of society from the upper classes in Indonesia. Of a total of about 265 million people, $40 \%$ are middle class and $20 \%$ are classified as lower class, plus as many as 25.67 million are categorized as poor or $9.66 \%$ of the population (Syariah, 2018).

Based on data on the percentage of the community's economic condition, it is necessary to develop the economic community of the people that are suitable for the majority of the community, namely through KUMKM and optimization of Islamic social funds such as zakat, infaq and alms. This is what makes Baitul Maal wat Tamwil relevant and highly accepted by the majority of Indonesian people who are Muslim (Syariah, 


\author{
KHAZANAH MULTIDISIPLIN \\ VOL 1 NO 22020 \\ https://journal.uinsgd.ac.id/index.php/kl
}

2018).

Growth in the number of BMT's is arguably quite rapid, since its inception around the beginning of the year 2000 until now it has stood around 4,500 units (Salama, 2018), even though that number is doubtful, the fact is in the field. The growth and widespread BMT distribution is not balanced with good data collection. This originated from the unclear BMT arrangements in Indonesia, where regulations and supervision still overlap between related regulators. Further related to this, there is no match on the number of BMT data in Indonesia, both active and inactive, including their respective financial positions. In addition, many BMTs are found that cannot maintain their performance and existence (Syariah, 2018).

The existence of Baitul Maal wat Tamwil (BMT) is expected to be able to encourage the micro and small business sector so that it can reduce poverty levels. This is considered important because BMT is a driving force for the Indonesian economy. The number of Indonesian citizens who are entrepreneurs of the MSME sector continues to increase every year. Even the distributed credit. Starting from Rp. 458.16 trillion in 2011 and continues to increase every year until it reaches Rp. 781.91 trillion in 2016 (Salama, 2018).

The intelligence of human resources from Baitul Maal wat Tamwil (BMT) is needed in formulating accurate strategies to maintain its existence in the midst of developing problems in the community environment (Sudarsono, 2003). One strategy that can be considered is to improve human resources that do not meet the criteria, especially in terms of knowledge and education levels that are not relevant.

Employees are among the key stakeholders who must be satisfied to ensure the achievement of the company's vision and mission (Sofwatama, Widjaya, \& Affandi, 2017). BMT is demanded to increase resources through formal and non-formal education because collaboration with educational institutions that have relevance to this cannot be ignored (Sakti, 2013).

The people's economy is the main target of Baitul Maal wat Tamwil 
KHAZANAH MULTIDISIPLIN

VOL 1 NO 22020

https://journal.uinsgd.ac.id/index.php/kl

as a sharia microfinance institution, through a profit-sharing economic system that seeks to improve small and medium-scale micro productive businesses to achieve their goal of trying to reduce poverty (Muljadi, 2013). The financial institution Baitul Maal wat Tamwil has been investigated by Muljadi to significantly empower small and medium or lower class people. (Muljadi, 2013).

The crucial Baitul Maal Tamwil (BMT) product is financing that is channeled to micro, small and medium enterprises (MSMEs). The role of MSMEs is to absorb workers. So indirectly, MSMEs contribute to reducing unemployment in Indonesia, which means it can increase the income per capita of people in Indonesia. Rising per capita income also contributed to the growth and development of the economy in Indonesia (Prastiawati \& Darma, 2016).

Based on the various explanations above, there are several things that can be concluded in BMT management practices in Indonesia.

It is necessary to improve the quality of human resources so that it is not seen as a number number profession for college graduates, although there are some exceptions in some large BMTs, such as Baitul Tamwil Muhammadiyah (BTM) found in Wiradesa, Pekalongan, Central Java. BMT must continuously improve expertise and skills of human resources, both from the practical aspects of operations and aspects of compliance with sharia principles.

The failure of the Baitul Maal wat Tamwil was mostly not caused by mismanagementand the Baitul Maal wat Tamwil (BMT) system which was considered to be inadequate, but because of an error in choosing targets or operational locations. Site selection is one of the main factors for successful BMT management. For this reason, managers must place their office locations in areas close to markets or business locations that require funds in micro, small and medium scale.

There must be synergy between Islamic banking and Baitul Maal wat Tamwil. BMT can be a bridge between Islamic banking and micro and small 
KHAZANAH MULTIDISIPLIN

VOL 1 NO 22020

https://journal.uinsgd.ac.id/index.php/kl

entrepreneurs. BMT can be the party that manages the financing channeled1 of Islamic banking to micro and small entrepreneurs: with a positive synergy built between Islamic banking and BMT increasingly positive impact in increasing the growth of the real sector.

Developing IT-based technology that can facilitate and make BMT performance more efficient to be applied to BMT in Indonesia. Sophisticated technology can improve BMT services to customers, accelerate information connectivity between employees and customers, time and energy efficiency, and data collection becomes much better and integrated with each other.

\section{CONCLUSION}

Based on the discussion that has been described, it can be seen that Baitul Maal wat Tamwil (BMT) has a function as a social institution and economic or financial institution, as a social Baitul Maal wat Tamwil (BMT) is more directed at efforts to collect and distribute non-profit funds such as zakat, infaq, sadaqah and or grants. As for the Baitul Maal wat Tamwil (BMT) financial institution tasked with collecting funds from the public (BMT members) who entrust their funds to be stored in BMT and channeling funds to the public(BMT members) who are provided with BMT funding, the financing channeled by BMT is expected to develop MSMEs. and gradually reduce poverty and unemployment. As an economic institution, BMT has the right to carry out economic activities, such as managing trade, industry and agriculture.

\section{REFERENCE}

Arif, M. N. R. Al. (2012). Lembaga Keuangan Syariah: Suatu Kajian Teoretis Praktis. Bandung: Pustaka Setia.

Arikunto, S. (2008). Prosedur penelitian suatu pendekatan Praktek. Cet.12. Jakarta: PT. Rineka Cipta.

Aziz, M. A. (2005). Pedoman Penilaian Kesehatan BMT. Jakarta: Pinbuk Press.

Badan Pusat Statistik. (2019). Profil Kemiskinan di Indonesia Maret 2019. (57), 1-8.

Dewi, N. (2017). Regulasi Keberadaan Baitul Maal wat Tamwil (BMT) 
KHAZANAH MULTIDISIPLIN

VOL 1 NO 22020

https://journal.uinsgd.ac.id/index.php/kl

dalam Sistem Perekonomiandi Indonesia. Serambi Hukum, 11(1), 96110.

Imaniyati, N. S. (2010). Aspek-Aspek Hukum BMT. Bandung: Citra Aditya Bakti.

Muljadi. (2013). Prospektif Baitul Maal wat Tamwil dalam Pengentasan Kemiskinan di Indonesia. 1(1), 62-69.

Mursid, F. (2018). Kebijakan Regulasi Baitul Maal wat Tamwil (BMT) di Indonesia. 18(2), 9-29.

Prastiawati, F., \& Darma, E. S. (2016). Peran Pembiayaan Baitul Maal wat Tamwil Terhadap Perkembangan Usaha dan Peningkatan Kesejahteraan Anggotanya dari Sektor Mikro Pedagang Pasar Tradisional. $17(2)$, https://doi.org/10.18196/jai.2016.0055.197-208

197-208.

Ridwan, M. (2004). Manajemen Baitul Maal wa Tamwil. Yogyakarta: UII Press.

Sakti, A. (2013). PEMETAAN KONDISI DAN POTENSI BMT: Kemitraan dalam Rangka Memperluas Pasar dan Jangkauan Pelayanan Bank Syariah kepada Usaha Mikro. Al-Muzara'ah, 1(1), 1-18. https://doi.org/10.29244/jam.1.1.1-18

Salama, S. C. U. (2018). Babak Baru BMT di Indonesia. Diambil dari https://www.medcom.id/ekonomi/analisa-ekonomi/5b2VgYvbbabak-baru-bmt-di-indonesia

Sholahuddin, M. (2011). Kamus Istilah Ekonomi, Keuangan dan Bisnis Syariah A-Z. Jakarta: PT. Gramedia Pustaka Utama.

Sofwatama, H., Widjaya, S., \& Affandi, I. (2017). Keberhasilan Kinerja Usaha Lembaga Keuangan Mikro Syariah Baitul Maal wat Tamwil LRisma (LKMS Bmt L-Risma) di Provinsi Lampung. Jiia, 5(1), 57-66.

Sudarsono, H. (2003). Bank dan Lembaga Keuangan Syariah: Deskripsi dan Ilustrasi. Yogyakarta: Ekonisia.

Syariah, K. N. K. (2018). Sharing Platform Keuangan Mikro Syariah Berbasis Baitul Maal wat Tamwil (BMT). Diambil dari https://knks.go.id/isuutama/8/sharing-platform-keuangan-mikrosyariah-berbasis-baitul-maal-wat-tamwil-bmt

Zed, M. (2008). Metode Penelitian Kepustakaan. Jakarta: Yayasan Obor Indonesia.

Arif, M. N. R. Al. (2012). Lembaga Keuangan Syariah: Suatu Kajian Teoretis Praktis. Bandung: Pustaka Setia.

Arikunto, S. (2008). Prosedur penelitian suatu pendekatan Praktek. Cet.12. Jakarta: PT. Rineka Cipta.

Aziz, M. A. (2005). Pedoman Penilaian Kesehatan BMT. Jakarta: Pinbuk 
KHAZANAH MULTIDISIPLIN

VOL 1 NO 22020

https://journal.uinsgd.ac.id/index.php/kl

Press.

Badan Pusat Statistik. (2019). Profil Kemiskinan di Indonesia Maret 2019. (57), 1-8.

Dewi, N. (2017). Regulasi Keberadaan Baitul Maal wat Tamwil (BMT) dalam Sistem Perekonomiandi Indonesia. Serambi Hukum, 11(1), 96110 .

Imaniyati, N. S. (2010). Aspek-Aspek Hukum BMT. Bandung: Citra Aditya Bakti.

Muljadi. (2013). Prospektif Baitul Maal wat Tamwil dalam Pengentasan Kemiskinan di Indonesia. 1(1), 62-69.

Mursid, F. (2018). Kebijakan Regulasi Baitul Maal wat Tamwil (BMT) di Indonesia. 18(2), 9-29.

Prastiawati, F., \& Darma, E. S. (2016). Peran Pembiayaan Baitul Maal wat Tamwil Terhadap Perkembangan Usaha dan Peningkatan Kesejahteraan Anggotanya dari Sektor Mikro Pedagang Pasar Tradisional. 17(2), 197-208. https://doi.org/10.18196/jai.2016.0055.197-208

Ridwan, M. (2004). Manajemen Baitul Maal wa Tamwil. Yogyakarta: UII Press.

Sakti, A. (2013). PEMETAAN KONDISI DAN POTENSI BMT: Kemitraan dalam Rangka Memperluas Pasar dan Jangkauan Pelayanan Bank Syariah kepada Usaha Mikro. Al-Muzara'ah, 1(1), 1-18. https://doi.org/10.29244/jam.1.1.1-18

Salama, S. C. U. (2018). Babak Baru BMT di Indonesia. Diambil dari https://www.medcom.id/ekonomi/analisa-ekonomi/5b2VgYvbbabak-baru-bmt-di-indonesia

Sholahuddin, M. (2011). Kamus Istilah Ekonomi, Keuangan dan Bisnis Syariah A-Z. Jakarta: PT. Gramedia Pustaka Utama.

Sofwatama, H., Widjaya, S., \& Affandi, I. (2017). Keberhasilan Kinerja Usaha Lembaga Keuangan Mikro Syariah Baitul Maal wat Tamwil LRisma (LKMS Bmt L-Risma) di Provinsi Lampung. Jiia, 5(1), 57-66.

Sudarsono, H. (2003). Bank dan Lembaga Keuangan Syariah: Deskripsi dan Ilustrasi. Yogyakarta: Ekonisia.

Syariah, K. N. K. (2018). Sharing Platform Keuangan Mikro Syariah Berbasis Baitul Maal wat Tamwil (BMT). Diambil dari https://knks.go.id/isuutama/8/sharing-platform-keuangan-mikrosyariah-berbasis-baitul-maal-wat-tamwil-bmt

Zed, M. (2008). Metode Penelitian Kepustakaan. Jakarta: Yayasan Obor Indonesia. 